\title{
Highlight report: physiologically-based modeling of diseased liver tissue
}

\author{
H. M. Bolt ${ }^{1}$
}

Received: 22 November 2017 / Accepted: 23 November 2017 / Published online: 25 November 2017

○) Springer-Verlag GmbH Germany, part of Springer Nature 2017

Recently, Arne Schenk et al. have published an interesting study to understand the relationship between the fraction of damaged liver tissue and loss of metabolic function (Schenk et al. 2017). Acute intoxication of the liver, for example, by carbon tetrachloride or paracetamol leads to destruction of a fraction of the hepatocytes (Godoy 2011). The fraction of destroyed hepatocytes can be quantified by immunostaining or more elaborate imaging techniques (Hoehme et al. 2010; Hammad et al. 2014; Ghallab et al. 2016). It can be expected that reduction of the number of hepatocytes leads to reduced metabolism of drugs and consequently increased half-life. In principle, three scenarios are possible: (1) the loss of tissue is directly proportional to the decrease of metabolic capacity, e.g., destruction of $30 \%$ of the hepatocytes decreases the amount of metabolites formed by $30 \%$; (2) loss of metabolic capacity is less compared to the fraction of lost hepatocytes. This would indicate that the surviving hepatocytes up-regulate their metabolic performance to compensate for the loss; (3) the loss of metabolic capacity goes beyond the mere loss of hepatocytes. Interestingly, this third scenario was observed by the authors and was named 'aggravated loss'. A probable explanation is that either the surviving hepatocytes express less metabolizing enzymes compared to healthy livers or the destroyed microarchitecture compromises function.

In recent years, much progress has been achieved in PBPK modeling (Kuepfer et al. 2016; Thiel et al. 2015; Jones et al. 2009; Meyer et al. 2012). Moreover, techniques of spatio-temporal tissue modeling have been established that allow simulations of how specific biological processes contribute to liver function (Hoehme et al. 2017; Friebel et al. 2015; Drasdo et al. 2014a, b; Schliess et al. 2014;

\section{H. M. Bolt}

bolt@ifado.de

1 IfADo-Leibniz Research Centre for Working Environment and Human Factors at TU Dortmund, Ardeystr. 67, 44139 Dortmund, Germany
Vartak et al. 2016). Such techniques allow the in silico analysis of which degree of loss of tissue causes loss of function (or metabolic capacity) under the assumption of a proportional relationship. As always, the model prediction has to be compared to the experimental data. For this purpose, Schenk et al. (2017) time-dependently analyzed the concentrations of a set of drugs (midazolam, torsemide, codein, talinolol, pravastatin and caffeine) in the portal vein and liver vein of mice and compared the situation in healthy mice and after $\mathrm{CCl}_{4}$ intoxication. The mechanisms of hepatotoxicity and their functional consequences are currently an intensively studied field of research (Kyriakides et al. 2016; Ghallab 2015; Mazzanti et al. 2015; Tolosa et al. 2015; Stöber 2016; Stoeber 2015a, b; Hammad 2013; El-Zawahry et al. 2016). The modeling techniques presented by Schenk et al. may certainly help to better understand the relationship between structural loss of tissue and its consequences on the function.

\section{References}

Drasdo D, Bode J, Dahmen U, Dirsch O, Dooley S, Gebhardt R, Ghallab A, Godoy P, Häussinger D, Hammad S, Hoehme S, Holzhütter HG, Klingmüller U, Kuepfer L, Timmer J, Zerial M, Hengstler JG (2014a) The virtual liver: state of the art and future perspectives. Arch Toxicol 88(12):2071-2075. https://doi. org/10.1007/s00204-014-1384-6 (No abstract available)

Drasdo D, Hoehme S, Hengstler JG (2014b) How predictive quantitative modelling of tissue organisation can inform liver disease pathogenesis. J Hepatol 61(4):951-956. https://doi.org/10.1016/j. jhep.2014B.06.013

El-yamany I et al (2016) Nigella sativa and Aloe vera protection against doxorubicin hepatotoxicity. J Exp Appl Animal Sci (S.l.) 2(1):10 22. https://doi.org/10.20454/jeaas.2016.1079 (ISSN 2314-5692). http://www.m-sciences.com/index.php?journal=jeaas\&page $=$ ar ticle\&op=view\&path\%5B\%5D=1079. Accessed 18 Nov 2017

Friebel A, Neitsch J, Johann T, Hammad S, Hengstler JG, Drasdo D, Hoehme S (2015) TiQuant: software for tissue analysis, quantification and surface reconstruction. Bioinformatics 31(19):32343236. https://doi.org/10.1093/bioinformatics/btv346

Ghallab A (2015) Highlight report: acetaminophen hepatotoxicity. Arch Toxicol 89(12):2449-2451. https://doi.org/10.1007/s00204015-1631-5 (No abstract available) 
Ghallab A, Cellière G, Henkel SG, Driesch D, Hoehme S, Hofmann U, Zellmer S, Godoy P, Sachinidis A, Blaszkewicz M, Reif R, Marchan R, Kuepfer L, Häussinger D, Drasdo D, Gebhardt R, Hengstler JG (2016) Model-guided identification of a therapeutic strategy to reduce hyperammonemia in liver diseases. J Hepatol 64(4):860-871. https://doi.org/10.1016/j.jhep.2015.11.018

Godoy P (2011) Hepatotoxicity. EXCLI J 10:124-127

Hammad S (2013) Advances in 2D and 3D in vitro systems for hepatotoxicity testing. EXCLI J 12:993-996 (No abstract available)

Hammad S, Hoehme S, Friebel A, von Recklinghausen I, Othman A, Begher-Tibbe B, Reif R, Godoy P, Johann T, Vartak A, Golka K, Bucur PO, Vibert E, Marchan R, Christ B, Dooley S, Meyer C, Ilkavets I, Dahmen U, Dirsch O, Böttger J, Gebhardt R, Drasdo D, Hengstler JG (2014) Protocols for staining of bile canalicular and sinusoidal networks of human, mouse and pig livers, threedimensional reconstruction and quantification of tissue microarchitecture by image processing and analysis. Arch Toxicol 88(5):1161-1183. https://doi.org/10.1007/s00204-014-1243-5

Hoehme S, Brulport M, Bauer A, Bedawy E, Schormann W, Hermes M, Puppe V, Gebhardt R, Zellmer S, Schwarz M, Bockamp E, Timmel T, Hengstler JG, Drasdo D (2010) Prediction and validation of cell alignment along microvessels as order principle to restore tissue architecture in liver regeneration. Proc Natl Acad Sci USA 107(23):10371-10376. https://doi.org/10.1073/ pnas.0909374107

Hoehme S, Friebel A, Hammad S, Drasdo D, Hengstler JG (2017) Creation of three-dimensional liver tissue models from experimental images for systems medicine. Methods Mol Biol 1506:319-362

Jones HM, Gardner IB, Watson KJ (2009) Modelling and PBPK simulation in drug discovery. AAPS J 11(1):155-166. https://doi. org/10.1208/s12248-009-9088-1

Kuepfer L, Niederalt C, Wendl T, Schlender JF, Willmann S, Lippert J, Block M, Eissing T, Teutonico D (2016) Applied concepts in PBPK modeling: how to build a PBPK/PD model. CPT Pharmacomet Syst Pharmacol 5(10):516-531. https://doi.org/10.1002/ psp4.12134

Kyriakides M, Maitre L, Stamper BD, Mohar I, Kavanagh TJ, Foster J, Wilson ID, Holmes E, Nelson SD, Coen M (2016) Comparative metabonomic analysis of hepatotoxicity induced by acetaminophen and its less toxic meta-isomer. Arch Toxicol 90(12):3073-3085
Mazzanti G, Di Sotto A, Vitalone A (2015) Hepatotoxicity of green tea: an update. Arch Toxicol 89(8):1175-1191. https://doi. org/10.1007/s00204-015-1521-x (Review)

Meyer M, Schneckener S, Ludewig B, Kuepfer L, Lippert J (2012) Using expression data for quantification of active processes in physiologically based pharmacokinetic modeling. Drug Metab Dispos 40(5):892-901. https://doi.org/10.1124/dmd.111.043174

Schenk A, Ghallab A, Hofmann U, Hassan R, Schwarz M, Schuppert A, Schwen LO, Braeuning A, Teutonico D, Hengstler JG, Kuepfer L (2017) Physiologically-based modelling in mice suggests an aggravated loss of clearance capacity after toxic liver damage. Sci Rep 7(1):6224. https://doi.org/10.1038/s41598-017-04574-z

Schliess F, Hoehme S, Henkel SG, Ghallab A, Driesch D, Böttger J, Guthke R, Pfaff M, Hengstler JG, Gebhardt R, Häussinger D, Drasdo D, Zellmer S (2014) Integrated metabolic spatial-temporal model for the prediction of ammonia detoxification during liver damage and regeneration. Hepatology 60(6):2040-2051. https:// doi.org/10.1002/hep. 27136

Stöber R (2016) Pathophysiology of cholestatic liver disease and its relevance for in vitro tests of hepatotoxicity. EXCLI J 15:870-871. https://doi.org/10.17179/excli2016-864 (No abstract available)

Stoeber R (2015a)Transcriptomic signature for drug-induced steatosis. EXCLI J 14:1259-1260

Stoeber R (2015b) Drug-induced mitochondrial impairment in liver cells. EXCLI J 14:1297-1299

Thiel C, Schneckener S, Krauss M, Ghallab A, Hofmann U, Kanacher T, Zellmer S, Gebhardt R, Hengstler JG, Kuepfer L (2015) A systematic evaluation of the use of physiologically based pharmacokinetic modeling for cross-species extrapolation. J Pharm Sci 104(1):191-206. https://doi.org/10.1002/jps.24214

Tolosa L, Gómez-Lechón MJ, Donato MT (2015) High-content screening technology for studying drug-induced hepatotoxicity in cell models. Arch Toxicol 89(7):1007-1022. https://doi.org/10.1007/ s00204-015-1503-z (Review)

Vartak N, Damle-Vartak A, Richter B, Dirsch O, Dahmen U, Hammad S, Hengstler JG (2016) Cholestasis-induced adaptive remodeling of interlobular bile ducts. Hepatology 63(3):951-964. https://doi. org/10.1002/hep.28373 